\title{
A SINGULAR HABIT OF SAWFLY LARVÆ
}

By W. M. Wheeler and W. M. Mann.

The following casual observations made in two widely separated South American localities seem worth recording as we have been unable to find any published account of similar behavior among the larvæ of New World sawflies.

July 16, 1920, the attention of the senior author was attracted to a very conspicuous, compact mass of sawfly larvæ crawling like a hugh slug over the short grass and sandy soil along the side of a trail through the jungle near Kartabo, British Guiana. The mass was about ten inches long, four inches broad and two inches thick in the middle. It was elongate elliptical and rather pointed at each end and retained its shape and size unaltered as it progressed like a single organism over the substratum. It consisted of about 200 larvæ, each an inch long and of a deep metallic blue color (Fig. 1). Further investigation of of this singular mass was cut short by a heavy tropical shower. A number of the larvæ were hastily thrown into a vial of alcohol. Although the senior author hoped to find the larvæ in the same locality under conditions more favorable for study, they were not again encountered either by him or by any of the other workers at the Tropical Laboratory.

The junior author had occasion to study a migrating mass of the same or of a closely related sawfly larva during February 1922, on the forest trail between the Mission and the edge of the pampa, near Cavinas on the Rio Beni, in Bolivia. The mass which he encountered was about a foot long, three or four inches broad at the middle, narrowed in front and behind and thickest in the middle. It, too, consisted of more than a hundred dark metallic blue larvæ of the same size as those observed by the senior author. The mass was also moving along as a compact unit and from a distance looked like a gigantic Planarian. When a pair of forceps was thrust into the midst of the larvæ and a number of them thrown out to the side, those in front and behind 
slowed up, appeared to be disturbed and jerked from side to side. The ejected individuals immediately headed for the mass and crawled into it and the whole, thus redintegrated, then quickened its pace and was soon moving along as before.

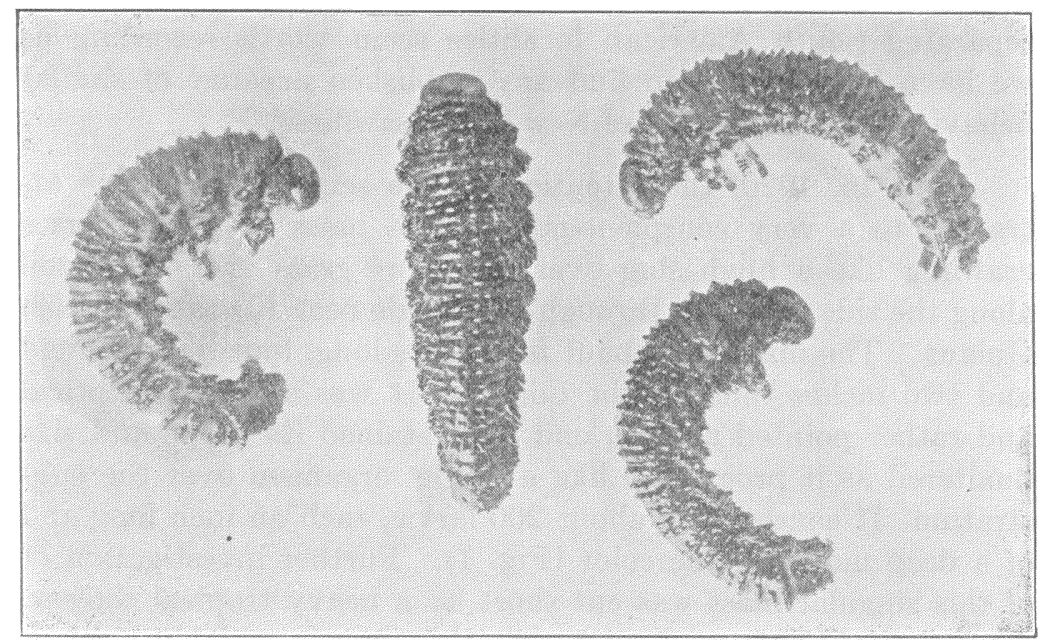

Fig. 1. Sawfly larvae from Kartabo, Brirish Guiana. X $12 \frac{3}{3}$

Mr. S. A. Rohwer kindly examined a number of the larvæ taken at Kartabo and reported as follows: "I regret that I am unable to help you very much with the identification of these specimens. We know so little about the larvæ of exotic sawflies and especially about those from South America. The only thing I can do is to guess as to the group to which your specimens belong. They remind me very much of the larva of Perga, and as this group is not represented in South America, but is replaced by another subfamily, I venture to suggest that your specimens belong to the family Perreyidæ, subfamily Syzygoniidæ ( Philomastiginæ of my classification of 1910). I imagine that the crawling larva you saw were in their last feeding stage and were looking for a place for pupation. I should also imagine that they had fed gregariously and that they would cocoon gregariously. Perhaps their cocoons will resemble those of the Australian genus 
Perga or those of the subfamily Argiinæ; that is, they would have a single, more or less impervious cocoon surrounded by a loosely woven, reticulate, outer cocoon which would be covered with long hair."

Such literature as we have been able to consult on the habits of the Australian saw-flies of the genus Perga proves to be very interesting in connection with the South American larvæ referred by Mr. Rohwer to the family Perryidæ. Froggatt (1891, 1901 and 1918) has published notes on the larval habits of several species of Perga. Concerning one of them, the "steel-blue sawfly", P. dorsalis Leach, he says (1918): "The gregarious larvæ feed at night, and rest during the day, clustered together in an oval mass, on the stem of the gum-tree upon which they are feeding. When disturbed, they exude a sticky yellow substance from the mouth, at the same time raising the tip of the body, and tapping it down on the foliage. The leaves are devoured from the top of the young gum trees; and when the larvæ are full fed, they crawl down the stem to pupate. I have found them fully developed in the middle of April; but when they descend from their resting place, they wander about over the grass for several days before they finally select a place in which to pupate, generally the softer soil against a tree-trunk. Into this they burrow to a depth of three or four inches, massing their large, oval cocoons in rows, one against the other. I watched several large swarms feeding upon the Peppermint-gums (Eucalyptus novce-anglice) at our Experiment Station at Uralla, and afterwards in their erratic wanderings over the grass; and marked down their final resting place and dug up the cocoons. At Binalong, in April, I observed two large swarms marching in massed formation; the heads of the hind rows always rested upon those in front as they moved along steadily together. Every now and then, the front rank came to a dead stop, when they all rested for three or four minutes; then a number began raising up and tapping down the tip of the abdomen, whereupon the whole band took up the motion; the leading ranks made a fresh start, and all moved along again. In the largest band, I counted two hundred and fifty caterpillars." 
Social tendencies are revealed not only by the Perga larvæ and pupæ, but also in the extraordinary protection of the young larvæ by the mother saw-fly. Lewis (1836) long ago described this behavior in $P$. lewisi Westwood of Tasmania, and Froggatt (1901), who says that this is "the commonest sawfly about Sydney on bloodwood" (Eucalyptus corymbosa), records his own observations as follows: "The female makes a double slit on the upper surface of the leaf generally among the young growth, in which she inserts a double row of elongate eggs, which, as they swell form a regular blister, but the most remarkable fact in the life history of this insect is the care she takes after laying her eggs. Nearly all insects after the eggs are laid leave them to their fate, but Lewis' saw-fly not only stands guard over them until they are hatched but further looks after the helpless grubs for some time after they have commenced feeding. She straddles the eggs with her wings half opened, the tip of her abdomen turned up, and with her jaws open, makes a slight buzzing sound if meddled with; if you pick her up, she never attempts to fly, but crawls back to her post, reminding one of an old hen protecting her chicks. The grubs when full grown are slightly under $1 \frac{1}{2}$ inches in length, general colour dull brown to dirty yellow, covered with short brown hairs, the last abdominal segment yellow. When full grown they crawl into the ground and form the typical form of cocoon, generally in regular rows."

\section{LITERATURE.}

1836. Lewis, R. H. Case of Materna! Attendance on the Larva by an Insect of the Tribe of Terebrantia, belonging to the genus Perga, observed at Hobarton, Tasmania. Trans. Ent. Soc. London 1, 1836, pp. 232-234.

1891. Froggatt, $W . W$. Notes on the Life-history of Certain Saw-flies (Genus Perga) with Description of a New Species. Proc. Linn. Soc. New South Wales 5, 1891, pp. 283-288. 
1901. $\ldots \ldots \ldots \ldots$ The Pear and Cherry Slug (Eriocampa limacina Retz), generally known as Selandria cerasi, with Notes on Australian Sawflies. Agric Gazette N. S. Wales 1901, pp. 1-11, 4 pls.

1918. Notes on Australian Sawflies (Tenthredinidæ). Proc. Linn. Soc. N. S. Wales 43 , 1918, pp. 668-726.

\section{TWO NEW ANTS FROM BOLIVIA}

(Results of the Mulford Biological Exploration.-Entomology.)

By Wm. M. ManN.

BUREAU OF ENTOMOLOGY, U. S. DElARTMENT OF AGRICULTURE.

Among the material collected in Bolivia and so far studied, two ants are of especial interest. One belongs to an aberrant undescribed genus of "driver ant" (Dorylinæ) and the other is a Ponerine species very similar to Probolomyrmex filiformis Mayr known from workers described in 1901, from Port Elizabeth, Cape Colony. The latter is an example of discontinuous distribution, such as is frequently found among the Ponerine anta. but it is the first case in its subfamily of a South African and South American relationship.

\section{Subfamily Dorylince}

\section{Leptanilloides gen. nov.}

Worker.-Small, slender, monomorphic. Head elongate, subquadrate, anterior portion of front rather strongly impressed. Clypeus short. Frontal carinæ very short, fused between the antennæ, separated anteriorly and bordering the antennal fossæ. Cheeks with a strong carina, which projects forward as a blunt tooth. Mandibles with distinct basal and apical portions separated by a rounded angle. Eyes absent. Antennæ 12-jointed, stout, scape short, funiculus moderately thickened distally, 

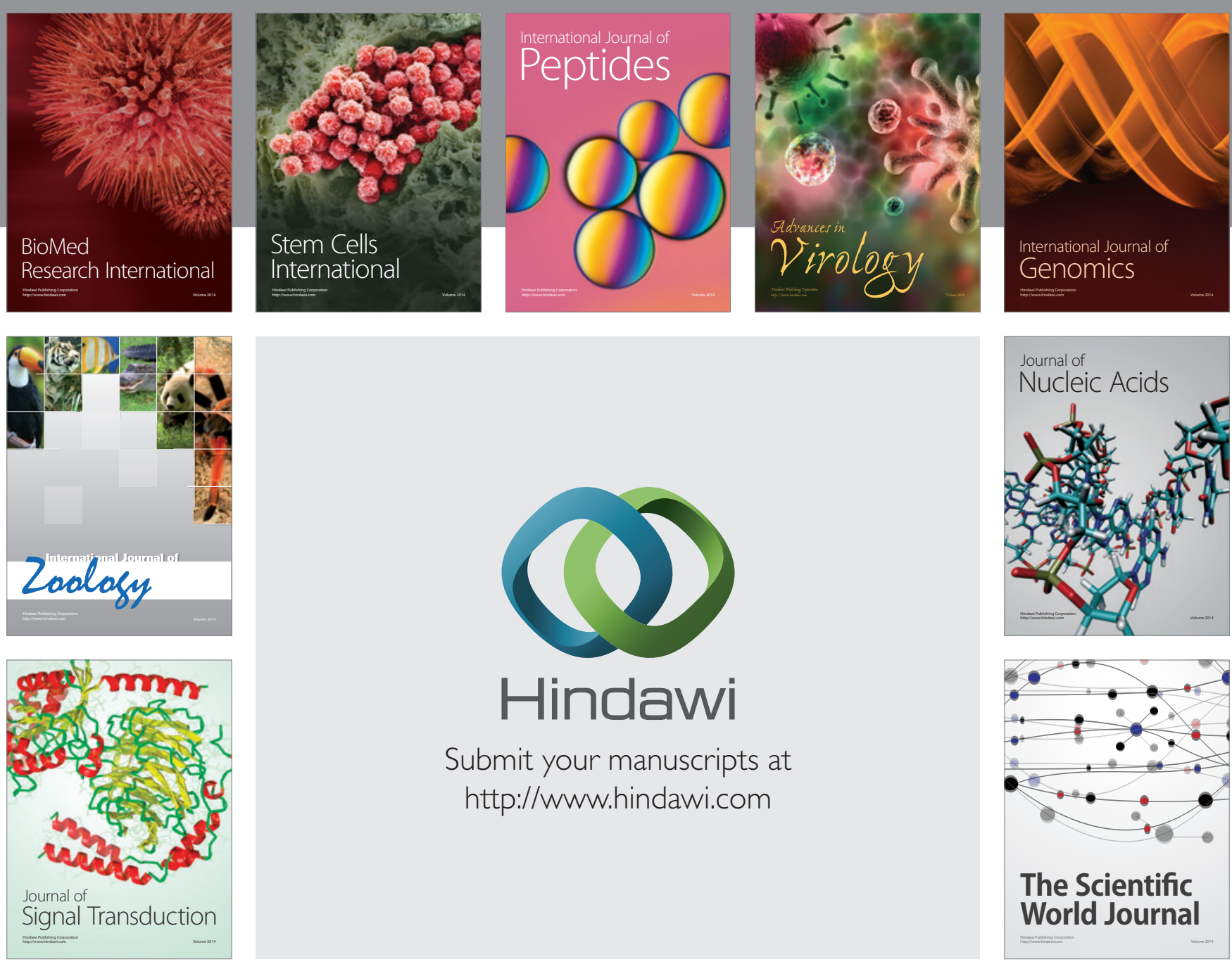

Submit your manuscripts at

http://www.hindawi.com
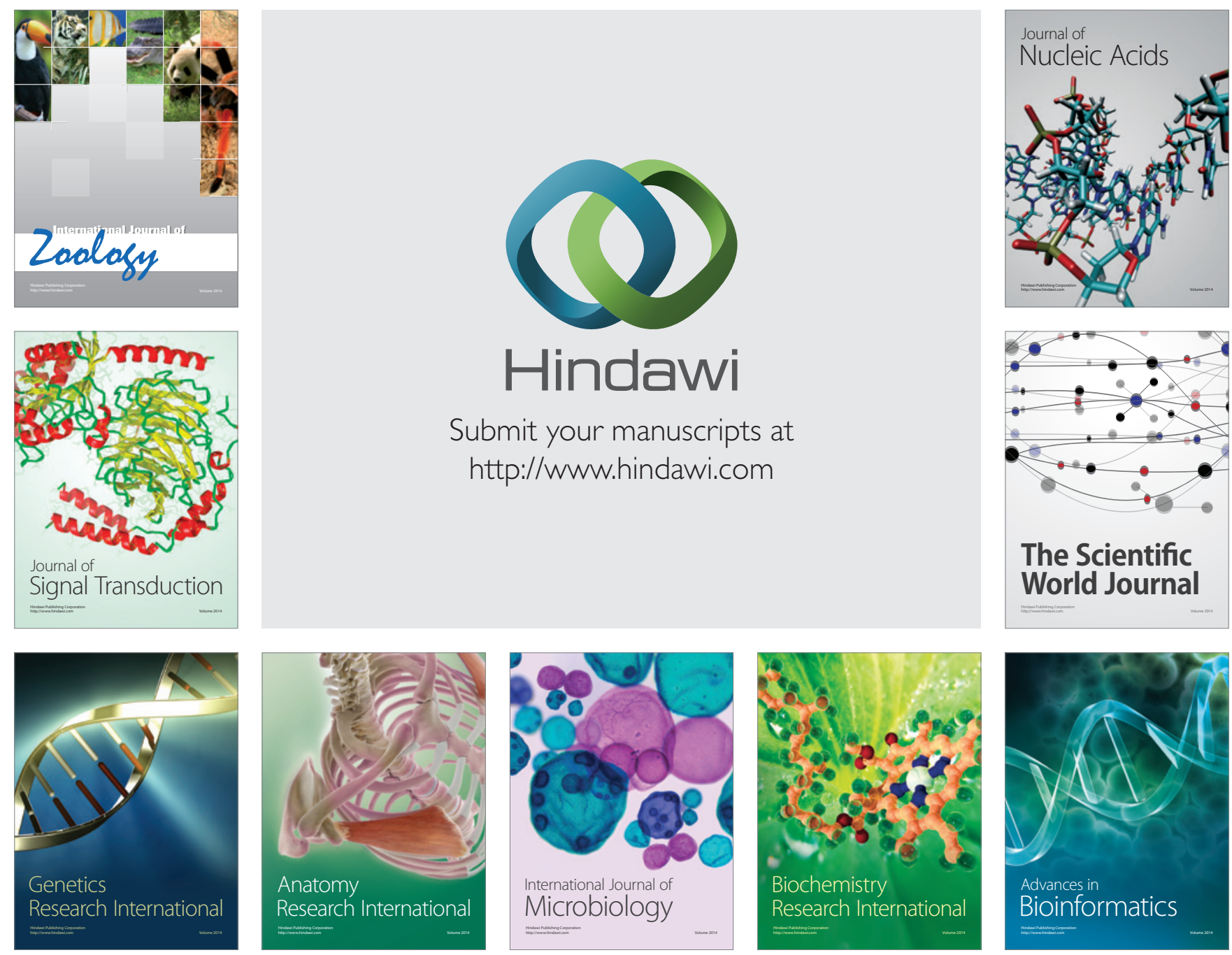

The Scientific World Journal
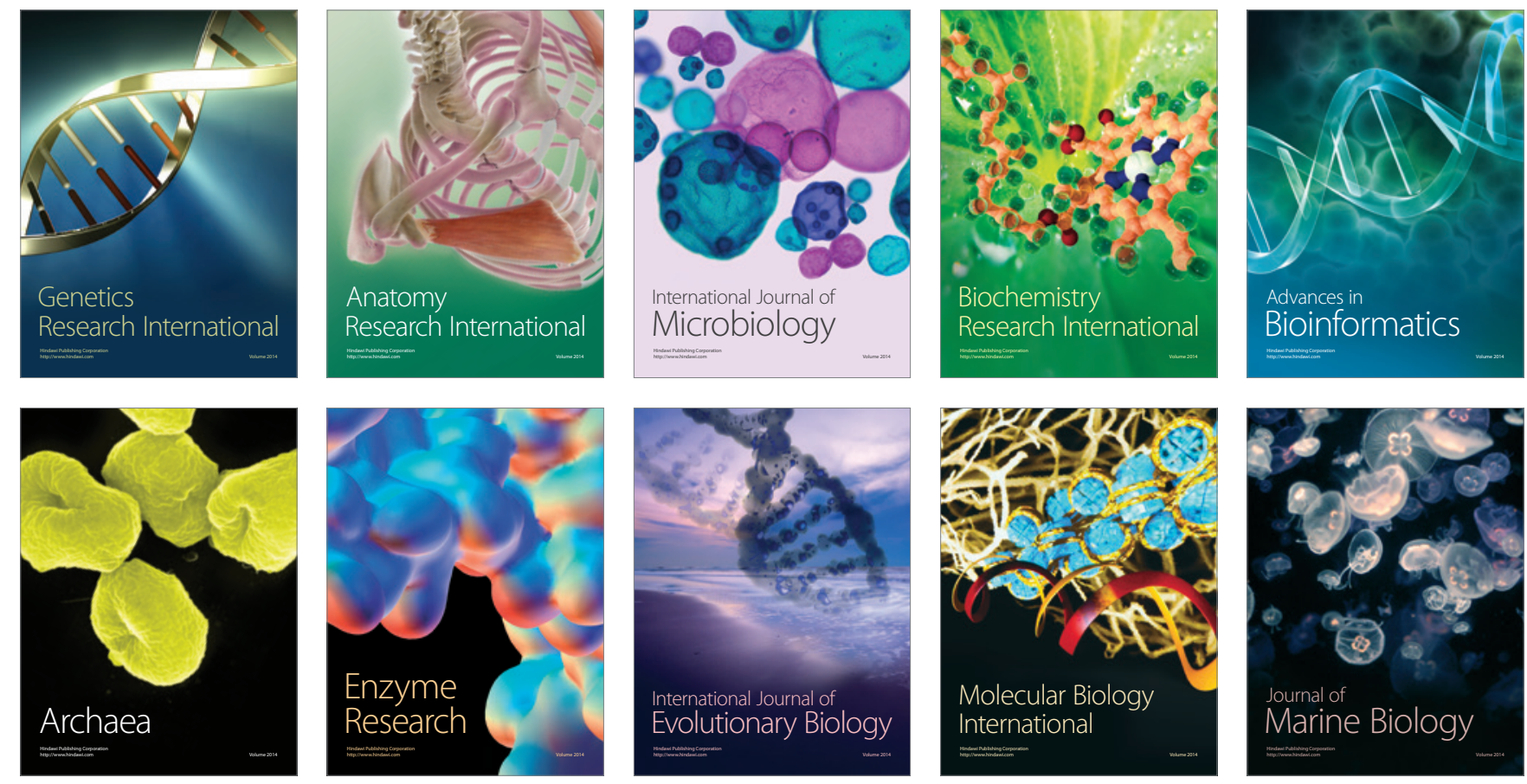